\title{
Bremer's "Gordian Knot": Transitional Justice and the US Occupation of Iraq
}

\author{
Eric Stover, ${ }^{*}$ Hanny Megally, ${ }^{* *} \&$ Hania Mufti***
}

\begin{abstract}
Shortly after the US invasion and occupation of Iraq, L. Paul Bremer III, in his capacity as the chief administrator of the Coalition Provisional Authority (CPA), introduced several transitional justice mechanisms that set the
\end{abstract}

\footnotetext{
* Eric Stover is Director of the Human Rights Center at the University of California, Berkeley, and Adjunct Professor in the School of Public Health. In 1991, Stover led a team of forensic scientists to northern Iraq to investigate war crimes committed by Iraqi troops during the Anfal campaign against the Kurds in the late 1980s. In March and April 2003, he returned to northern Iraq where he and Hania Mufti monitored the compliance with the 1949 Geneva Conventions by all sides to the conflict. He returned to Iraq in February 2004 to assist Mufti in investigating the status of documentary and physical evidence to be used in trials against Saddam Hussein and other members of the Ba'athist Party. His most recent book, The Witnesses: War Crimes and The Promise of Justice in The Hague, was published by the University of Pennsylvania Press in 2005.

** Hanny Megally is Director of the Middle East and North Africa (MENA) program of the International Center for Transitional Justice. As head of the Middle East department at the International Secretariat of Amnesty International, he took delegations in the late 1980s and early 1990s to the neighboring countries of Iran, Kuwait, Bahrain, and Saudi Arabia to interview refugees and to investigate human rights violations committed by the regime in Iraq. In July 2003, as executive director of the MENA division of Human Rights Watch, he headed delegation to Iraq for meetings with officials of the CPA and the Iraqi Governing Council and representatives of the bar association, local human rights groups, and media. He returned to Baghdad in March 2004 for further meetings related to the implementation of transitional justice mechanisms in Iraq.

*** Hania Mufti is Regional Director of the Middle East and North Africa division of Human Rights Watch. She has researched and written numerous reports for Amnesty International and Human Rights Watch on violations of human rights and international humanitarian law committed by the government of Saddam Hussein. She is the author of the report The New Iraq? Torture and III-treatment of Detainees in Iraqi Custody, published by Human Rights Watch in January 2005. Her work in Iraq was profiled in the March 2005 issue of The Atlantic Monthly (see William Langewiesche, "The Accuser: The Case Against Saddam Hussein, and the Woman Who Built It," Vol. 295 The Atlantic Monthly (Mar. 2005)).
} 
course for how Iraqis would confront the legacy of past crimes for years to come. In developing these mechanisms, Bremer consulted with a select group of Iraqi exiles that had returned to Iraq or were still living abroad. However, he failed to solicit the opinions and attitudes of the Iraqi people as a whole. He also failed to consult many of the governmental and nongovernmental entities that could pass on to the CPA and future Iraqi governments the "lessons learned" and "best practices" gleaned from transitional justice processes in other countries. As a result, many of the mechanisms introduced by Bremer either backfired or were hopelessly flawed.

\section{INTRODUCTION}

In early March 2003, weeks before the US invasion of Iraq, CIA officials and senior military commanders gathered at Camp Doha, Kuwait to plan for the eventual siege of Baghdad by US and coalition forces. Intelligence officials were convinced that Iraqis would rush to the streets to welcome American soldiers as they rode triumphant into the Iraqi capital. One CIA operative suggested that US special forces and Iraqi sympathizers should sneak hundreds of small American flags into the country for Iraqis to wave at their liberators. The agency would capture the spectacle on film and beam it throughout the Middle East. It would be the ultimate photo-op designed to win the "hearts and minds" of doubters back in the United States and throughout the Arab world.

But the idea was quickly quashed by the US commander of allied ground forces, Lt. General David McKiernan, who told those assembled at the meeting that US troops had been instructed not to brandish the flag so as to avoid being perceived as an occupying army. Undeterred, the CIA officials continued to press the military officers for some form of pageantry to celebrate what they saw as an imminent military victory for the United States and its coalition allies. "At first, it was going to be US flags," a military officer who attended the meeting recalled, "and then it was going to be Iraqi flags. The flags are probably still sitting in a bag somewhere."

The debate in the war room at Camp Doha illustrates the dilemma that the United States faced as coalition forces swept into Baghdad. Having destroyed Saddam's military and security apparatus, the thinking went, American soldiers would be viewed as liberators and not as occupiers. By capitalizing on the good will of the Iraqi people the Americans could quickly scale back their military presence and bring in civilian experts to

1. See Michael R. Gordon, Faulty Intelligence Misled Troops at War's Start, N.Y. Times, 20 Oct. 2004, at A1. 
help a new Iraqi government, headed by expatriates like Ahmed Chalibi, create a new democratic state. "Of course," writes Larry Diamond, a former Senior Advisor to the Coalition Provisional Authority in Iraq, "these naïve assumptions quickly collapsed, along with overall security, in the immediate aftermath of the war. US troops stood by helplessly, outnumbered and unprepared, as much of Iraq's remaining physical, economic, and institutional infrastructure was systematically looted and sabotaged." ${ }^{2}$ Then, as spring turned into summer, a nascent insurgency, comprised of foreign fighters and Saddam loyalists, began to emerge from the rubble, creating a security quagmire that would last for the foreseeable future.

Amid this growing chaos, L. Paul Bremer III, a career diplomat in the US Department of State and an expert on terrorism and homeland security, arrived in Iraq to serve as the chief administrator of the Coalition Provisional Authority, or CPA. Bremer's job was to unravel the "Gordian Knot" of a postwar Iraq and to steer it toward a legitimate and viable future. In addition to rebuilding Iraq's overall economy and society, Bremer had to deal with a palatable demand for justice after thirty-five years of despotic rule and massive human rights abuses. ${ }^{3}$

Bremer issued several directives in the first month of his tenure in Iraq that would set the course for how Iraqis would confront the legacy of past crimes for years to come. ${ }^{4}$ Most notable (and controversial) was the introduction of a de-Ba'athification program on 16 May 2003 to remove members of the Ba'ath Party from their positions of authority and to ban them from future employment in the public sector. Another decree, issued on 10 December 2003, created the Iraqi Special Tribunal for Crimes Against

2. Larry Diamond, What Went Wrong in Iraq, 83 For. AfF. 34, 36 (2004).

3. Reflecting on the Allied occupation on Germany after World War II, the British historian Geoffrey Best captured the conundrum the American occupiers faced in Iraq: "International law expects of decent occupiers a sort of juggling act. They are expected to maintain as much as they can of the normal character amenities of life in the occupied territories, at the same time as they must be allowed to maintain their own presence and security there." See Geoffrey Best, War and Law Since 1945118 (1994). For a discussion of the obligations of an "occupying power," also see Caryle Murphy, Occupation of Territory, in Crimes of War: What the Public Should Know 263-64 (Roy Gutman \& David Rieff eds., 1999).

4. The Coalition Provision Authority Orders are available at www.cpa.gov/government/ governingcouncil.html. Several orders deal with transitional justice measures, including Coalition Provision Authority Order No. 1, De-Ba'thification of Iraqi Society, CPAORD/ 16 May 2003/01; Coalition Provision Authority Order No. 2, Dissolution of Entities, CPAVORD/23 May 2003/02; Coalition Provision Authority Order No. 7, Penal Code, CPA/ORD/10 June 2003/07; Coalition Provision Authority Order No. 13 (Revised), The Central Criminal Court of Iraq, CPA/ORD/18 June 2003/13; Coalition Provision Authority Order No. 15, Establishment of the Judicial Review Committee, CPAORD/23 June 2003/ 15; Coalition Provision Authority Order No. 35, Re-establishment of the Council of Judges, CPA/ORD/21 Sept 2003/35. 
Humanity (Special Tribunal) ${ }^{5}$ to try Iraqi nationals or residents of Iraq accused of genocide, ${ }^{6}$ crimes against humanity, and war crimes. He also mandated a series of administrative and institutional directives, including the establishment of a property claims commission, a central criminal court, and a new Iraqi army and civil defense corps.

This article examines how Bremer's directives affected the process of transitional justice in Iraq and how ordinary Iraqis perceived these processes at the time. Our methods of research included interviews with dozens of Iraqi, US, and British officials, forensic scientists, and representatives of the United Nations and nongovernmental organizations. We also conducted on-site visits to mass graves throughout Iraq and to governmental and nongovernmental institutions that possess Iraqi state documents obtained during and after the war. ${ }^{7}$ Finally, to understand how Iraqis would like to deal with their legacy of human rights violations and political violence, we drew on data obtained from extensive interviews and focus group discussions conducted in July and August 2003 with representatives from a broad cross-section of the Iraqi population by a team of researchers from the International Center for Transitional Justice (ICTJ) and the Human Rights Center of the University of California, Berkeley. ${ }^{8}$

Iraq's confrontation with its violent past presents one of the most complex cases of transitional justice since the end of World War II. First,

5. The jurisdiction of the Iraqi Special Tribunal covers the crimes mentioned above as well as violations of stipulated Iraqi laws committed from 17 July 1968 to 1 May 2003. CPA Order No. 48, Delegation of Authority Regarding an Iraqi Special Tribunal, available at www.iraqcoalition.org/regulations/20031210_CPAORD_48_IST_and_Appendix_A.pdf. Article 14 of the statute provides:

The Tribunal shall have the power to prosecute persons who have committed the following crimes under Iraqi law: a) For those outside the Judiciary, the attempt to manipulate the judiciary or involvement in the functions of the judiciary, in violation, inter alia, of the Iraqi interim constitution of 1970, as amended; b) The wastage of national resources and the squandering of public assets and funds, pursuant to, inter alia, Article 2(g) of Law Number 7 of 1958, as amended; and c) The abuse of position and the pursuit of policies that may lead to the threat of war or the use of the armed forces of Iraq against an Arab country, in accordance with Article 1 of Law Number 7 of 1958, as amended.

ld. at 14-5.

6. Early in 1959 the government of Iraq, a military dictatorship, signed the Convention on the Prevention and Punishment of the Crime of Genocide. See Convention on the Prevention and Punishment of the Crime of Genocide, adopted 9 Dec. 1948, 78 U.N.T.S. 277 (entered into force 12 Jan. 1951) (entered into force for U.S. $23 \mathrm{Feb} .1989$ ).

7. See Human Richts Watch, Iraq: State of the Evidence (2004), available at hitp://www.hrw.org/ reports/2004/iraq1 104/iraq1104text.pdf.

8. International Center for Transitional Justice (ICTJ) \& Human Rights Center, University of California, Berkeley (HRC Berkeley), Iraqi Volces: Atmitudes Toward Transitional Justice and Social ReConstruction (2004) [hereinafter ICT), IraQI Voices], available at www.ictj.org/ downloads/IraqDesigned.pdf. A total of 395 people were surveyed through thirty-eight key informant interviews and forty-nine focus group discussions, between 18 July and 13 August 2003. 
there is the sheer magnitude and severity of the crimes Saddam Hussein committed against the Iraqi people. The prior regime left thousands of government opponents executed, more than 300,000 missing and likely dead, thousands of towns and villages across the country destroyed, all dissent crushed, and hundreds of thousands internally displaced or living in exile abroad. This legacy of massive crimes has crippled Iraq and left it vulnerable to internal violence and civil war. Unless a middle ground can be found that brings those responsible for past crimes to justice while not singling out one group at the expense of others, Iraq faces the danger of further bloodshed and turning into a terminally weak state.

Second, deep-seated tensions within Iraqi society over identity, the US occupation, and future political power will determine how effective any transitional justice process will be in Iraq. Having lived under an autocratic state that imposed a single Iraqi identity for decades, Iraqis emerged from the war torn between defending that civic identity and their own ethnic and religious identities. Nowhere was this more evident than in the Kurdish areas to the north and the Shia areas to the south, where both groups had suffered terrible human rights abuses during $\mathrm{Ba}^{\prime}$ athist rule. After the war, many Shia and Kurds were wary of how their groups would be affected by a new central government. Tensions also emerged between those Iraqis who supported the US occupation and those who opposed it. Meanwhile many Sunnis, and especially those openly supported Saddam, feared that a new Iraqi government, and especially one that contained an overwhelming majority of Shia or Kurds, would target Sunnis as a scapegoat for the crimes of the past.

Third, in a post-conflict situation like Iraq in which the state has collapsed, security trumps everything: It is the central pedestal that supports all else. Without some level of security, transitional justice processes are doomed to fail. Court officials cannot guarantee the safety of potential witnesses, let alone the security of their own investigators. Nor can they secure mass graves and other crime scenes. Without security, courthouses and other places where people might gather to provide testimony to truth commissions remain vulnerable to armed attack.

Fourth, by the time of Bremer's arrival in Iraq, insecurity in Baghdad had turned the US occupation into a physical and psychological bunker. "Separated from Iraqis by the formidable security around the three-squaremile 'Green Zone' (where the CPA was based) and around the CPA's regional and provincial headquarters," the American civilians had little, if any, contact with the Iraqi people. ${ }^{9}$ Indeed, the CPA (which ruled Iraq from May 2003 until June 2004) made no significant effort to consult Iraqis about

9. Diamond, supra note 2 , at 39 . 
the transitional justice processes that were intended to help them confront a violent past. When consultations did take place they tended to be between CPA officials and Iraqi exiles that had returned to Iraq or with members of the CPA-appointed Iraqi Governing Council (ICC). As a result, Iraq's transitional justice process could potentially be viewed as an American process operating under an Iraqi façade.

Finally, simmering tensions between the United States and the United Nations over the legality and necessity of the war had severely limited the participation of foreign experts in the process of transitional justice in Iraq. By "going it alone," the US had alienated many of the very governmental and nongovernmental entities that were best poised to pass on to the Iraqis the "lessons learned" and "best practices" gleaned from similar transitional processes in other countries. Iraqis found they had limited access to international expertise ostensibly because only experts willing to work directly with the CPA, and receiving funding from the US government, were available to provide their knowledge and skills. Meanwhile, other experts, and particularly those working with nongovernmental organizations, were left watching or merely critiquing from the sidelines.

Societies emerging from periods of war or political repression can deal with the past in a number of ways. They can pursue criminal trials, establish truth commissions, initiate vetting and lustration programs to remove past offenders from the public sector, provide reparations to victims, and institute legal and institutional reforms to conform to international standards of human rights. All of these activities comprise the main components of transitional justice. ${ }^{10}$ Yet for such mechanisms to be effective in postwar societies they must meet three tests.

First, it is imperative that the wider population view the implementing authorities as both legitimate and impartial. Second, such measures should be selected through a genuine process of consultation with those most affected by the violence. To the extent possible, all sectors of a war-ravaged society-the individual, community, society, and state-should become engaged participants in-and not merely auxiliaries to-the processes of transitional justice and social reconstruction-though, undoubtedly, at different times and in different ways." Victims must receive formal acknowledgment and recognition of the grave injustices and loss that they suffered.

10. For a description of the range of transitional justice mechanisms, see generally MaRTHA Minow, Between Vengeance and Forgiveness: Facing History after Genocide and Mass Viotence (1998); ICTJ, IRAQI VoICES, supra note 8.

11. This was the finding of a five-year study of justice and social reconstruction in Rwanda and the former Yugoslavia conducted by the Human Rights Center, University of California, Berkeley. See My Neighbor, My Enemy: Justice and Community in the Aftermath of Mass Atrocity (Eric Stover \& Harvey M. Weinstein eds., 2005). 
Families of the disappeared must be able to recover, bury, and memorialize their dead. Bystanders-those who did not actively participate in violence, but who also did not actively intervene to stop abuses-should come to recognize that their passivity contributed to the maintenance of a repressive state. Perpetrators must be held accountable for their crimes so as to validate the pain and suffering of victims and to communicate publicly that the past horrors deserve societal condemnation. At the same time, accountability measures should be implemented in a manner that avoids stigmatizing the communities from which the perpetrators come.

Finally, to work effectively, transitional justice measures must be accompanied by programs that promote political reconstruction of a legitimate and capable state, economic and social reconstruction, freedom of movement, security and the rule of law, access to accurate and unbiased information, educational reform, and cross-ethnic engagement. ${ }^{12} \mathrm{Critical}$ to the development and implementation of these programs is the recognition that changes in one part of the system can reverberate through the system as a whole. Consequently, those who initiate transitional justice mechanisms must be mindful of how each new intervention or policy affects the aggregate. Such measures must work synergistically, with no single component aspiring to address all the needs of a postwar society. Each decision, each policy, has consequences, both expected and untoward. The challenge is to monitor and respond to these particular elements while at the same time seeing the whole picture.

In the end, the US-led process of developing and implementing mechanisms of transitional justice in Iraq failed on all three accounts. In this article, we explain why.

\section{ACCOUNTABILITY}

At war's end, it was clear that something had to be done quickly to jump start a process of transitional justice in Iraq, if only to protect key documentary and physical evidence for future trials. By mid-May 2003, Iraqis, desperate to find their missing and executed family members, had begun using their own means to exhume mass graves throughout the country. Lacking adequate forensic expertise and international assistance, they began opening graves in a manner that would prevent forensic identification of most—if not all_-of the remains. ${ }^{13}$ For example, at two sites

12. Id. at 327-39.

13. Eric Stover, William D. Haglund \& Margaret Samuels, Exhumation of Mass Graves in Iraq: Considerations for Forensic Investigations, Humanitarian Needs, and the Demands of Justice, 290 J. AM. MED. Assn. 663-66 (2003). 
located near the Mahawil military base just north of the southern Iraqi city of Hilla, villagers used a backhoe to dig up more than 2,000 sets of remains, gouging and commingling countless skeletons in the process, while some families used their hands to dig for bones and shards of clothing and carted them away in wheelbarrows and buckets. ${ }^{14}$

The grim spectacle at the Hilla burial pits drew protests from international human rights groups that criticized the US and other coalition authorities for not implementing a plan to help Iraqis recover the remains of their relatives in a dignified manner and to preserve evidence that might convict those responsible for these crimes. In late May 2003, the CPA's predecessor, the US Office of Reconstruction and Humanitarian Assistance, announced that it would take measures to secure grave sites, to launch a media campaign to explain to the public the necessity of preserving grave sites, and to request governments to send forensic teams to Iraq to exhume graves prioritized for forensic investigation. ${ }^{15}$

In the meantime, hundreds of thousands of Iraqi state documents that could have proven critical in future trials of suspected human rights offenders were lost or destroyed. ${ }^{16}$ While US and coalition forces reportedly seized an estimated nine linear miles of documents many other files were pilfered, looted, or otherwise destroyed needlessly, resulting in the loss of potentially vital information. Some of the destruction took place in the context of the widespread looting in Baghdad and elsewhere, carried out within sight of the coalition troops that had apparently received no instructions about securing this material or protecting the premises in which it was found.

Not only was valuable trial evidence being lost, but the failure to protect security archives had the potential of contributing to retaliatory violence and vengeance killings, since the archives could identify thousands of security agents and informers by name. Moreover, a thriving trade in the sale and purchase of Iraqi state archives had emerged in Baghdad and other major cities. The representatives of three Iraqi political parties admitted to us that that they had purchased documents-in some cases on the open market, in other cases when approached by individuals hoping to make a quick sale. One estimated that the number of documents bought through individual sales accounted for as much as forty percent of his party's total collection. ${ }^{7}$ Under these conditions, it was likely that a

14. Human Rights Watch, The Mass Graves of Al-Mahawil: The Truth Uncovered (May 2003), available at www.hrw.org/reports/2003/iraq0503/.

15. US Office of Reconstruction and Humanitarian Assistance, Mass Graves Action Plan (2003).

16. See Press Release, Human Rights Watch, Iraq: Protect Government Archives from Looting (10 Apr. 2003), available at http//www.hrw.org/press/2003/04/iraq041003.htm.

17. Human Rights Watch, Iraq: State of the Evidence, supra note 7. 
substantial number of faked or forged materials were being injected into the documentation pool.

Amidst this chaos, international human rights groups called on the UN Security Council to appoint a commission of experts, as it had done for the former Yugoslavia and Rwanda, to recommend the best option for moving ahead with a tribunal. While the idea of a commission received the enthusiastic backing of the UN Secretary General's Special Representative to Iraq, Sergio Viera de Mello, it failed to gain traction in the Security Council. In April 2003, the Bush administration announced plans for an "Iraqi-led" trial process and, three months later, the IGC established a judicial commission to set up special court to investigate and to prosecute former government officials.

It was clear from the start that the Iraqi commission and its backers in Washington, DC, had little appetite for anything other than an all-Iraqi court, a position that troubled many international human rights groups. As Human Rights Watch wrote in July 2003:

The Iraqi judiciary, weakened and compromised by decades of Ba'ath party rule, lacks the capacity, experience, and independence to provide fair trials for the abuses of the past. Few judges in Iraq, including those who fled into exile, have participated in trials of the complexity that they would face when prosecuting leadership figures for acts of genocide, crimes against humanity, or war crimes. ${ }^{18}$

Yet the prevailing view in Baghdad and Washington was that any future tribunal, with the exception of defense lawyers, had to be purely Iraqi. Some Iraqi jurists told us that seeking assistance from international experts would be acceptable but only for the purposes of sharing expertise with their Iraqi counterparts. Others said that the plethora of evidence of past crimes, in the form of forensic, documentary, and testimonial evidence, would make the task of convicting members of Saddam Hussein's government a relatively simple affair. They accepted the notion of seeking international expertise to help in the investigative stage, and especially in the effort to gather forensic evidence from mass graves, but rejected the idea of having foreign jurists involved in any forthcoming trials. Privately, some Iraqi political leaders supported an international tribunal, while others were prepared to consider the option and ensure that it was discussed by the ICG.

Notwithstanding Iraq's strong and legitimate desire to be in charge of its transitional justice process, few if any Iraqi jurists, including those who had returned from exile, were knowledgeable about recent developments in the field of international criminal justice. Effectively shut off from the outside

18. See Press Release, Human Rights Watch, Iraq: Justice Needs International Role (15 July 2003), available at www.hrw.org/press/2003/07/iraq071503.htm. 
world for decades, they knew little about the newly established International Criminal Court (ICC) or the ad hoc international tribunals for Rwanda and the former Yugoslavia. Nor did they have access to the jurisprudence generated by the ad hoc courts on topics such as command responsibility, joint criminal enterprise, and complicity doctrine. To compound matters, Iraqi courts had virtually no experience dealing with complex criminal trials involving serious crimes under international law. Iraq's Penal Code, adopted in 1969, made no mention of war crimes, crimes against humanity, or genocide. ${ }^{19}$

Much of the antipathy toward international participation in Iraqis transitional justice process was due in large measure to the Bush Administration's opposition to the ICC and any involvement by the United Nations in Iraq's internal affairs. ${ }^{20}$ The US also turned a cold shoulder to the expertise and considerable experience of nongovernmental human rights organizations such as Amnesty International, Human Rights Watch, and the International Center for Transitional Justice, which were concerned that the flaws of the new tribunal would be locked into place once the first trial began. During the summer and fall of 2003, the CPA and the IGC legal affairs committee consistently denied requests by these groups to comment on drafts of the law establishing the Special Tribunal. In private, some CPA officials said that they supported greater international consultation and even recognized the merits of a hybrid (national-international) tribunal. But, in the end, they succumbed to the desire of Iraqi jurists and politicians who wanted to manage the process themselves. Some CPA officials felt that the drafting process, because of political considerations, was moving too fast and that consultations had in fact been very limited. In late September 2003, a CPA official told us that the consultation process was over and all that remained was some "fine-tuning" of the text before it was to be sent to Paul Bremer.

Bremer signed the order establishing the Special Tribunal on 10 December 2003. ${ }^{21}$ In its critique of the court's statute, Human Rights Watch noted that many of its provisions were in accord with international standards of human rights and international humanitarian law and that the definitions of punishable crimes were consistent with those contained in the

19. Some Iraqi judges argued that while Iraq's Penal Code does not include genocide in the list of crimes, any defendants facing this charge could be tried under Article 406 of the Code, which deals with murder including mass murder. Law 111 of 1969, art. 406, Iraq Penal Code and Amendments, 6th Edition (2000) (on file with authors).

20. This position had changed somewhat by March 2004 as terrorist and insurgent violence increased and the Bush Administration realized that certain activities, such as elections, would be best managed by the United Nations.

21. Coalition Provisional Authority Order No. 48, supra note 5. 
statutes of the ICC and other international criminal courts. But the organization also criticized the statute for disregarding essential fair trials guarantees, including the admission as evidence of confessions obtained through coercion. It also said the Statute failed to set standards that would insure that judges and prosecutors possessed adequate experience and could function in an independent and impartial manner. ${ }^{22}$ The organization called on the United Nations not "to lend its legitimacy and expertise" to what it called a "fundamentally flawed" tribunal that was inherently vulnerable to political manipulation. ${ }^{23}$

One of the most contentious issues surrounding the Special Tribunal's statute was the use of the death penalty. ${ }^{24}$ Some UK officials based in Baghdad objected to its inclusion, especially as Paul Brenner had suspended its application for the duration of the occupation. ${ }^{25}$ Yet, these same British officials said that there was little they could do given the US government's support of the death penalty ${ }^{26}$ and strong Iraqi public opinion in favor of its use against past human rights offenders. For their part, Iraqi political leaders we spoke to, while recognizing the necessity of breaking with a violent past, believed that the desire of Iraqis for retribution through the application of the death penalty far outweighed the financial benefits of gaining international acceptance of future trials. In the meantime, international human rights organizations argued that the Special Court's use of the death penalty would send the message that the court wished to exact vengeance rather than render justice. ${ }^{27}$

22. Human Richts Watch, Memorandum to the Iraqi Governing Council on 'The Statute of the IraqI Special Tribunal' (Dec. 2003) [hereinafter Memorandum to the Iraqi Governing Council], available at www.hrw.org/backgrounder/mena/iraq121703.htm.

23. Human Rights Watch, Iraq: Flawed Tribunal Not Entitled to U.N. Legitimacy (6 Jan. 2004), available at http://hrw.org/english/docs/2004/01/15/iraq6942.htm.

24. The death penalty was suspended in Iraq first by General Tommy Franks, the former US Central Command chief, in April 2003 and then by the CPA on 10 June 2003 through order number 7 (section 3(1)). See Coalition Provisional Authority Order No. 7, supra note $4, \S 3(1)$. Under Article 24(a) of the statute of the Special Tribunal, penalties for offenses "shall be those prescribed by Iraqi law. . . ." The death penalty is permissible under Iraqi law for certain offenses in some circumstances. Under Article 24(e), penalties that "do not have a counterpart under Iraqi law shall be determined by the Trial Chambers taking into account such factors as the gravity of the crime, the individual circumstances of the convicted person and relevant international precedents." See Coalition Provisional Authority Order No. 48, supra note 5, art. 24.

25. Coalition Provisional Authority Order No. 7, supra note 4, § 3. Section 3 states: “Capital punishment is suspended. In each case where the death penalty is the only available penalty prescribed for an offense, the court may substitute the lesser penalty of life imprisonment, or such other lesser penalty as provided for in the Penal Code."

26. Some CPA officials told us privately that the death penalty was slowing down the process of gathering and analyzing forensic evidence. Many medicolegal experts, it seemed, wished to have no part in a judicial process that included the death penalty. Yet other CPA officials said it was a non-issue.

27. Human Rights Watch, Memorandum to the Iraqi Governing Council, supra note 22, at 8. 
By early January 2004, a month after the establishment of the Special Tribunal, it had become clear that neither the Iraqi authorities nor the CPA had taken sufficient steps toward the gathering and preservation of court evidence. Nor had they identified "local talent" that could work with international experts in the preparation of evidence for the trials. As a result, Washington dispatched a team of legal advisers to Baghdad to assess what needed to be done. The team, led by the State Department's Ambassador for War Crimes, Pierre-Richard Prosper, was comprised of legal advisers from the Department of Justice and the Department of Defense. Prosper told us that the team had set out four priorities for its visit: (1) to advise the Iraqis on how to launch "a campaign to sell the tribunal to the Iraqi people" as a prelude to the gathering of testimonial evidence by investigators; (2) to find an administrator for the Special Tribunal as a first step towards its institutionalization; (3) to advise the Iraqi officials on appointments of both Iraqi and international investigators for the tribunal; and (4) to make security arrangements for the protection of tribunal personnel, particularly judges, prosecutors, and investigators.

Prosper's trip led to significant changes in the US government's backstage handling of the Special Tribunal. In late January 2004, the US Department of Justice, with a budget of US $\$ 75$ million, took primary responsibility for preparing prosecution cases against Saddam Hussein and other members of his government. In March, a Regime Crimes Liaison Office (RCLO) was established under CPA authority to take responsibility for gathering, organizing, and assessing the evidence to be used in the trials. It also assumed the responsibility of training personnel with the Special Tribunal. In late May, Greg Kehoe, a US attorney with ICTY prosecutorial experience, was appointed as RCLO Adviser and deployed in Baghdad.

US officials in Baghdad told us that they had every desire to "internationalize" the tribunal's team of advisers. Yet this aspiration failed to materialize. Some US officials acknowledged that non-prohibition of the death penalty in the tribunal's statute had discouraged some European experts who opposed capital punishment from coming forward but that ways had been found around it, such as having the UK and others contribute administrators and advisers to judges as opposed to prosecutors. The US contribution, by contrast, would consist mainly of analysts, investigators, and security personnel. Department of Justice officials expressed confidence that European and other experts would be brought on board, reiterating their commitment that it be an Iraqi-led process with an "advisory role" for the United States.

By September 2004, with more than forty of Iraq's most wanted war criminals, including Saddam Hussein, in custody, the Special Tribunal was in a state of disarray. Salem Chalabi, the American-educated lawyer who had been the court's chief administrator, had resigned and left the country. 
A deputy took over Chalabi's position only to be replaced by a loyalist to the acting primer minister. The court's rules and procedure had not been finalized. Efforts to find suitable jurists and prosecutors had resulted in only eleven appointments, far less than needed to investigate and try suspects charged with serious state crimes. ${ }^{28}$ When Saddam Hussein and eleven other codefendants were arraigned on 1 July 2004, the Special Tribunal was not in a position to take on the task. Instead, the arraignments took place under the jurisdiction of another CPA-established court, the Central Criminal Court of Iraq, applying Iraq's penal code rather than the Special Tribunal's statute. Several of the defendants, including Ali Hassan al-Majid, who is alleged to have led the chemical weapons attacks on Halabja on 16 March 1988 that killed at least 5,000 people, had sought legal counsel from elsewhere in the Arab world, but none had come forward. ${ }^{29}$

The Special Tribunal lacked a comprehensive plan for the collection, preservation, and analysis of physical and documentary evidence of past crimes. Since the overthrow of the Iraq government in April 2003, over 250 mass graves had been located across Iraq. ${ }^{30}$ Some are believed to contain the remains of thousands of victims, including entire families. By midOctober 2004, in the face of a deteriorating security situation, only two large-scale forensic investigations of mass graves had begun in Iraq, despite the CPA's initial plan to have several sites completed by the turn over of power to the Iraqis at the end of June. Similarly, the Special Tribunal, through the US-led Regime Special Crimes Office, was still negotiating with Iraqi nongovernmental organizations and political parties to gain access to the state archives in their possession. If and when the court took possession of the documents, it would need to verify their authenticity and link the information contained in them to individual suspects. ${ }^{31}$

In the meantime, interim Prime Minister Ayad Allawi had let it be known that he wanted the Special Tribunal to speed up its investigations so the first high-profile trial, probably against al-Majid, could begin soon. Asked to comment on the prime minister's call to accelerate the trials, Greg Kehoe, an advisor to the special crimes office replied (ironically), "He certainly didn't consult with me first." 32 Kehoe, who had investigated war crimes in the former Yugoslavia in the 1990s, doubted whether the court

28. The IST Statute provides for the appointment of one or more trial chambers, each comprising five trial judges, and nine judges to sit on the appeals chamber. See Coalition Provisional Authority Order No. 48, supra note 7.

29. See John F. Burns, For Hussein, a Spartan Life at His Former Palace, N.Y. Times, 19 Sept. 2004, at A1.

30. Human Rights Watch, State of the Evidence, supra note 7, at 2.

31. Id. at 20.

32. John F. Burns, US Official Says Early Trials of Huessin and Others Are Unlikely, Despite Allawi's Demand, N.Y. Times, 25 Sept. 2004, at A6. 
would be ready to begin its first trial until the first half of 2005 . The key in each case was establishing "command responsibility" for systematic and widespread killing that occurred under Hussein's rule, and that, he said, was a very "complex issue." ${ }^{33}$

Aware of the Special Tribunal's shortcomings, the US government sponsored a weeklong training program in international humanitarian law for forty-two Iraqi judges and prosecutors-almost the entire Special Tribunal-in October 2004. Citing serious doubts that the court could meet "relevant international standards," the UN Secretary General, Kofi Annan, barred top prosecutors and judges from the UN war crimes tribunal for the former Yugoslavia from attending the training program. A newspaper correspondent who was allowed to attend the seminar reported that both the Iraqi jurists and their hosts admitted that they had little grasp of what one Iraqi judged called "this whole new body of law." Three Iraqi judges told the correspondent that they felt "caught between international public opinion and the opinion of ordinary Iraqis. They wanted experienced judges from other nations to sit on the bench with them but feared that many Iraqis would see this as humiliating. ${ }^{34}$

\section{VETTING AND DE-BA'ATHIFICATION}

Vetting to remove abusive officials from positions of authority, if carried out fairly, properly, and prudently, can be a legitimate part of a larger process of institutional reform in periods of transition. It can also play an important role in ensuring that past abuses are not repeated. History of the last fifty years shows that countries trying to make transitions to democracy must inevitably bring back some members of the ousted regime.

After World War II, for example, the American occupiers in Germany came to realize that they lacked the necessary knowledge of German society to rebuild its institutions and that the country would not become a functioning liberal democracy without the cooperation and expertise of many of those tainted by the previous regime. In 1945, the Americans began their deNazification program with two overarching goals. The first involved the transfer of power to non-Nazis so that a stable, democratic, and peaceful Germany could emerge. The second was to punish those most guilty of war crimes and crimes against humanity in such a way that the German public would recognize that they had violated basic standards of a just society. This, it was hoped, would bring about a change in German values. Yet, the

33. Id.

34. Marlise Simons, Iraqis Not Ready for Trials: U.N. to Withhold Training, N.Y. Times, 22 Oct. 2004, at A11. 
emergence of Cold War politics and America's interest in strengthening and rearming Germany as an ally against the Soviets, coupled with the realization that deNazification efforts were both causing a loss of American prestige and respect in Germany and undermining Germany's reconstruction efforts, prompted the Americans to ease its Nazi purges and abandon its control of the program in 1949. ${ }^{35}$

More recently, a number of countries-Spain, Greece, Portugal, Argentina, Chile, Hungary, Czechoslovakia, Poland, the former East Germany, the Philippines, and South Africa, to name a few-faced the bedeviling question of what to do with those government officials who directly or indirectly participated in human rights abuses. Although in some cases moderate transitional justice measures were carried out-including truth commissions, reparations, purges of leaders and collaborators, and trials of some lower-level officials like border guards-most holdovers from the old regime were permitted to take part in the new order if only to help the country back on its feet.

When Paul Bremer arrived in Baghdad in May 2003 he set into motion a vetting and de-Ba'athification process (later adopted by the Iraqi Governing Council) that would have a profoundly destabilizing affect on Iraqi society. Indeed, Bremer and other CPA officials made the same mistakes as their Word War II predecessors: They saw the former Ba'ath members only as villains and troublemakers. They did not consider, as difficult as it might be, that the Baathists' skills and experience-and their political powermade them indispensable in the effort to rebuild post-war Iraq.

The Ba'ath Party-ba'ath means "renaissance" in Arabic-was founded in Syria in 1947 as a political vehicle to promote Pan-Arabism. In the 1950s, Syrian exiles and Iraqi students brought $\mathrm{Ba}^{\prime}$ athism to Iraq, which was then ruled by a military government. The Ba'athists came to power in 1963, in a coup that was followed by a bloodbath during which Ba'athists arrested, tortured, and killed their rivals. In 1968, in another coup, Saddam Hussein's wing of the Ba'ath Party took control of the country, and in 1979 Saddam declared himself president. By the time of the US occupation of Iraq, the Party, which kept its operations secret, was estimated to have had between 1 and 2.5 million members, most of them Sunnis, like Saddam. The Party had been virtually synonymous with Saddam Hussein's regime and the brutality it unleashed over its thirty-five years in power. Ba'athists were required to inform on their neighbors, their co-workers, and one another. At the same time, party members filled jobs at every level of society and anchored the middle class. ${ }^{36}$

35. See David Cohen, Transitional Justice in Divided Germany After 1945, in Retribution And Reparation (Jon Elster ed., 2005).

36. See Phebe Marr, The History of Modern Iraq (1985); Midde East Watch, Human Rights in Iraq (1990). 
For many Iraqi Shiites and Kurds, de-Ba'athification was an absolute necessity for a peaceful transition to democracy in Iraq. But the US-led coalition also needed to address the fears of the newly disenfranchised Sunnis, and, on a basic level, to keep the country functioning. In the end, Bremer opted to appease the Shiites and Kurds and issued a sweeping ban of Iraq's Ba'ath Party: all senior party members were barred from public life; lower-level members were also barred, but some could appeal. ${ }^{37}$ A week later, he disbanded the Iraqi Army.

Bremer's order removed the top four ranks of Ba'ath party members from their positions and banned them from future employment in state jobs. Other party members, regardless of rank, were sacked from the top three layers of management in all national government ministries, affiliated corporations, and other government institutions. The order, Bremer said, would apply to 15,000 to 25,000 individuals, roughly 1 percent of the party's 2 million members. Yet, over the next eighteen months, an estimated 30,000 party members, including some 6,000 to 12,000 educators, were summarily sacked from their posts. ${ }^{38}$

Bremer declared from the onset that Iraq's de-Ba'athifciaton program would be Iraqi-led. In late May 2004, he established an Iraqi De$\mathrm{Ba}^{\prime}$ athification Council (IDC) ${ }^{39}$ to investigate the identity and whereabouts of Ba'ath party officials and members involved in violations of human rights. ${ }^{40}$ The Council, whose members were appointed by Bremer, was mandated to investigate and gather information on the "extent, nature, location and current status of all Iraqi Ba'ath Party property." ${ }^{41}$ Individuals adversely affected by the decisions of the Council could appeal in writing to Bremer for a reversal and he retained the authority to grant exceptions on a case-by-case basis.

37. On May 16 Ambassador Bremer decreed the de-Ba'athification process in Coalition Provisional Order No. 1, supra note 4. This order stated that full members, meaning the ranks of 'Udw Qutriyya (Regional Command Member), 'Udw Far (Branch Member), 'Udw Shu 'bah (Section Member), and 'Udw Firqah (Group Member) were dismissed and banned from future employment. They were also evaluated for criminal conduct and as a security threat to the CPA. Individuals occupying the top three layers of management in every national government, affiliated corporation, or other government institution (universities, hospitals) were interviewed and investigated. Members holding more junior ranks such as ' $U d w$ (Member) and ' $U d w$ 'Amil (Active Member) were also eligible for dismissal. In all cases, the Administrator could grant exception on an individual basis.

38. L. Paul Bremer, Coalition Provisional Authority Press Briefing (25 Nov. 2003) (on file with authors).

39. Coalition Provisional Order No. 5, Establishment of the Iraqi De-Ba'Athification Council, CPA/ORD/25 May 2003/5. Order No. 1, issued by the Commission on 14 September 2004 , declared all Ba'ath party members from the rank of ' $U d w$ Firqah (group member) and above as dismissed from their positions and liable to punishment for disobeying this order. See Coalition Provisional Authority Order No. 1, supra note 4.

40. Id. § $3(1)(\mathrm{b})$.

41. Id. $\S 3(1)(\mathrm{a})$. 
It soon became obvious that the Council was serving largely at the whim of the CPA. ${ }^{42}$ In June, Bremer directed the Commander of Coalition Forces to establish several Accreditation Review Committees (ARCs) composed of two civilians and one military member (one of whom would be an Iraqi nominated by the Council) to undertake the functions previously vested in the Council. Bremer gave the US commander the power to use "military investigative resources" to compile information concerning possible Ba'ath party affiliations of employees at all ministries. In addition, the commander could augment or replace these resources with "US civilian investigators" and, whenever possible, "include professional Iraqis." ${ }^{\text {.43 }}$ Bremer noted that as the Council "demonstrates sufficient capability, the Administrator will task [it] to assume increasing and ultimately full responsibility for the process, subject to the authority, direction and control of the administrator. The ARCs shall remain in operation until the people of Iraq adopt a representative form of self-government." 44

In implementing its de-Ba'athification program, the CPA failed to consult the Iraqi people about the desirability of such a sweeping and often arbitrary process. A survey of a broad cross-section of the Iraqi population conducted by the International Center for Transitional Justice (ICTJ) and the Human Rights Center (HRC) at the University of California, Berkeley, in July and August 2003 found that while the majority of respondents blamed the Ba'ath party for past crimes and felt that those responsible should be dismissed, they also felt it was unfair to penalize individuals solely on the basis of their party membership and sought to draw distinctions between members of the party, whom they referred to as Ba'athists, and ardent

42. See generally Coalition Provisional Authority Memorandum No. 1, Implementation of De-Baathification Order No. 1, CPA/MEM/3 June 2003/01.

43. Id. $\S 2(1)$. In gathering the necessary information the investigators were to rely on sources such as interviews with the individual, public records and announcements, judgments of CPA senior ministry advisors, testimony of Iraqi colleagues, findings of the IDC, assessments of leading Iraqi political figures and government records revealing bonuses or other privileges associated with party membership. An investigator could then make a factual finding about a person's affiliation with the party, inform the individual and advise him/her that they have the right to appeal to the ARCs. The ARCs would not only hear appeals from Iraqis who felt wrongly accused of being Ba'athists but could also review applications prepared by investigators requesting individual exemptions from Order No. 1. The criteria the ARCs would use to grant or deny an exception included requiring the person to denounce the Ba'ath Party and his past association with it, whether the individual was a senior Ba'ath party member or simply a full party member, whether the individual has exceptional educational qualifications, whether the individual left the party before 16 April 2003 (the date of its outlawing by the CPA), whether the individual continues to command the support of colleagues and respect of subordinates, whether the individual is judged to be indispensable to achieving important Coalition interests, and whether the individual can demonstrate he joined the party to hold his job or support his family.

44. Id. $\S 1(2)$. 
supporters of Saddam Hussein, whom they termed Saddamists. While respondents in northern Iraq generally supported a purging of the Ba'ath party from government institutions, many respondents in central or southern regions expressed concern about the impact of wide-scale de-Ba'athification on the need for human resources to rebuild the country. ${ }^{45}$

As the vetting and lustration process got underway in Iraq, Bremer's aim of gradually handing over responsibility to the Council was soon overtaken by events on the ground. In the face of international criticism of Bremer's de-Ba'athification process, the Iraqi Governing Council set up the Higher National De-Ba'athification Commission (HNDC) in August 2003. The following month, Ahmad Chalabi, an extremely vocal proponent of deBa'athification and a leading voice in support of the war to topple Saddam, was appointed chairman of the commission. Chalabi, in turn, appointed a protégé Mithal al-Alusi as its director. The commission occupied two floors of a concrete office block inside the Green Zone. A poster on one wall bore the message "Ba'athists=Nazis."

The HNDC established an appeals process (which was retroactively ratified by CPA Memorandum No. 7 of 14 November 2003) to replace the one in place under the occupying authority's Armed Forces Commander. Under the HNDC procedures Director Generals (in the case of Ministries) or their equivalent (in the case of other public institutions) could issue advance notification explaining reasons for dismissals and providing details of the appeals process. Only individuals who held the rank of "group member" ( $U d w$ Firqa) or below or officials who held positions in the top three ranks of management in the public sector could appeal. No one of the rank of section member ('Udw Shu'bah) or above had the right to appeal. In addition, would-be appellants were given the blatantly unenviable choice of receiving their pensions if they accepted their dismissal notice or forgoing their pensions if they appealed.

According to a two-tiered appeals process, appellants could appeal to a local de-Ba'athification committee within two weeks of receiving their notice of dismissal and expect to hear within six weeks of their appeal. If denied, they could then appeal, within two weeks, to the HNDC itself and expect to hear within a further six weeks. The HNDC, acting as a higher appeals board, would include two judges appointed by the Judicial Council sitting alongside it. The signature of one of the two judges would be needed to ratify the decision of the HNDC. ${ }^{46}$ At least that was the theory.

On 14 September 2003, Chalabi issued two decisions confirming the

45. See ICTJ, IRAQI VoICES, supra note 8 .

46. The official procedures for carrying out de-Ba'athification in the public sector and within government offices and ministries is available in Arabic at the website of the Higher National DeBa'athification Council, available at www.debaath.org/page/ajr_h/ajw.htm. 
removal from public office of all full members who comprised the top four ranks of the Ba'ath Party and banning the nomination to public sector, the political sphere, organizations of civil society, the media, and broadcasting of anyone who had held the rank of group member ('Udw Firqa) or above. ${ }^{47}$ Chalabi's directives made it clear that the appeals process was increasingly more fiction than fact and could backfire by making disgruntled Ba'ath Party officials easy fodder for the insurgency. In response, the IGC sought to undo the damage by establishing central committees within the Ministries, aimed at reviewing individual cases and bringing back officials dismissed through the de-Ba'athification process and secondly enabling all those dismissed from the public to apply for retirement pensions. ${ }^{48}$ In November, in what seemed like catching up to a train that had already left the station, the CPA rescinded its original order establishing a de-Ba'athification council and empowered the Iraqi Governing Council, through the HNDC, to carry out the de-Ba'athification process. ${ }^{49}$ It also tried to wrest back control by calling on the HNDC to provide monthly reports to Bremer and to the IGC, including the names and positions of Iraqis dismissed from positions of employment as well as the names of any Iraqi citizens hired to replace a dismissed employee. ${ }^{50}$

But it was too late. By March 2004, Chalabi's aggressive measures had begun to take their toll. Most notable was the dismissal of 12,000 Iraqi teachers who had found their appeals blocked, or endlessly deferred, by the review process. One of Chalabi's aides later criticized the HNDC, calling it a "government within a government" for its wide-ranging mandate and extensive resources. ${ }^{51}$ Later that month Bremer intervened, ordering Chalabi to curb what senior American officials were now calling "overzealousness in the post-Saddam purge." ${ }^{52}$ In April, the CPA administrator, while still defending his de-Ba'athification program, acknowledged that it had had a negative affect in Iraq, especially in the country's schools and universities:

47. Decision Numbers $1 \& 2$ of 14 September 2003, issued by the HNDC, and signed by Ahmed Chalabi in his capacity as head of the HNDC are available at www.debaath.org/ page/ka_h/index.htm. The decisions banned from nominations anyone who was a member of Special Security, National Security, the special Presidential protection unit, military intelligence, Feda'yeen Saddam, and General Security services. Id.

48. Available at www.debaath.org/page/ka_h/52_k.htm. The committees would review individual cases and where they reached a two-thirds majority agree to bring back the dismissed official. One of the criteria to be taken into account by the Central committees was the "dire need" for the services of the dismissed person.

49. Coalition Provisional Authority Memorandum No. 7, Delegation of Authority Under DeBa'Athification Order No. 1, at Section 2(1), CPA/MEM/4 Nov. 2003/7.

50. Id. § $2(10)$.

51. Christopher Dickey, The Master Operator, Newsweek, 8 Mar. 2004, at 32.

52. John F. Burns \& lan Fisher, US Seeking to Stabilize Iraq Casts Ba'athists in Lead Role, N.Y. Times, 3 May 2004, at A1. 
[M]any Iraqis have complained to me that deba'athification policy has been applied unevenly and unjustly. I have looked into these complaints and they are legitimate. The deba'athification policy was and is sound. It does not need to be changed. It is the right policy for Iraq. But it has been poorly implemented. The requirement to join the party was strongly enforced among teachers and university professors. A group of teachers told me yesterday that poor execution of the deba'athification process has had a severe impact on teachers and university professors.

We cannot shortchange the children of Iraq. They are your future. I have discussed this matter with the Minister of Education, the Minister of Higher Education and with the Chairman of the deba'athification Commission. We have agreed that decisions made by local appeals committees of the Ministry of Education will be effective immediately. This will allow thousands of teachers to return to work. Thousands more will begin receiving pensions this week. Those primary and secondary school teachers formerly of the rank of firqah members whose appeals have not yet been heard will have their appeal adjudicated within 20 days. I have asked the Commission to handle the cases of hundreds of university professors with the same urgency. Professors who did not use their posts to intimidate others or commit crimes should be allowed to return to work promptly. ${ }^{53}$

By late June 2004, when the CPA dissolved itself, the process of de$\mathrm{Ba}^{\prime}$ athification had become a model of how not to do it. Initially, members of the Ba'ath Party were dismissed solely on the basis of belonging to the category of senior party member and without any reference to involvement in wrongdoing. However, to appeal successfully the burden of proof lay on the accused to prove no involvement in wrongdoing. Additionally, individuals were essentially blackmailed into choosing between appealing or receiving pensions and power was concentrated in the hands of one entity making an already non-transparent process vulnerable to the influence of individual political agendas. As a result, a significant number of party members were on the streets with no jobs, no way to sustain their families, and most importantly no reasonable explanation whatsoever for the situation they found themselves in. Many educated Iraqis were unable to perceive de-Ba'athification policy as anything but "collective punishment." 54

In seeking to rectify the missteps in this process the CPA and the IGC again erred on the side of making sweeping decisions affecting large numbers of Iraqis. The new policies aimed at restoring people, including former members of the Ba'ath Party, to jobs have been more focused on

53. L. Paul Bremer, III, Coalition Provisional Authority, Turning the Page: Baghdad (23 Apr. 2004) available at www.iraqcoalition.org/transcripts/20040423_page_turn.html.

54. Jonathan Steele, Anti-Baathist Ruling may Force Educated Iraqis Abroad, GuARDIAN, 30 Aug. 2003, at 16. 
needs for talent and skills than on principle. If an individual is indispensable within a ministry or is highly thought of by the rest of the faculty, they have been reinstated, thus creating a system of favoritism rather than one that upholds due process standards.

By September 2004, Iraq's de-Ba'athification program had emerged as a hotly contested political and security issue. On one side were several Shiite leaders and members of Chalabi's council, the HNDC, who argued that while the commission may have committed errors in the past, former $\mathrm{Ba}^{\prime}$ athists had been returned to their jobs through the appeals process. According to Ali Feisal al-Hamad, director of implementation at the HNDC, by November the Council had reviewed, annulled, and provisionally returned 15,000 of the 35,000 individuals dismissed by the CPA to managerial positions. The Council had retired a further 700 senior members, dismissed 3,000 not included in the original CPA action, and was reviewing 8,000 cases. ${ }^{55}$ On the other side were Iraqi officials such as Prime Minister Ayad Allawi who called for the disbanding of the de-Ba'athification commission and replacing it with a more lenient judicial system. The Ba'athist purges, Allawi and other IGC members argued, were undermining national unity and unwittingly winning the insurgents new recruits, a position shared by some American military commanders in the field. ${ }^{56}$ Other critics charged that the Commission's purpose was being distorted by some of its members who had business interests in blackballing Ba'athist businessmen that had accumulated wealth under the former regime. One day before hastily departing Baghdad, administrator Paul Bremer issued a memorandum paving the way for the disbanding of the HNDC as one of his final acts. ${ }^{57}$ Under Memorandum 100, revising many of the CPA orders, regulations, and provisions, Bremer withdrew the authority he had given to the HNDC under Memorandum 7 and authorized the interim Iraqi government to abolish the HNDC and to establish a new body in its place. ${ }^{58}$

55. E-mail from Ali Feisal al Hamad to Hanny Megally (13 Nov. 2004) (on file with authors). He adds that those reemployed underwent a rehabilitation course of several weeks and their employment would be subject to a review by the HNDC after one year, at which point they could be dismissed or permanently reemployed.

56. See Edward Wong \& Erik Eckholm, Allawi Presses Efforts to Bring Back Ba'athists, N.Y. TIMEs, 13 Oct. 2004, at A12.

57. See Coalition Provisional Authority Order No. 100, Transition of Law, Regulations, Orders, and Directives Issued by the Coalition Provisional Authority, CPAORD/28 June 2004/100. "Revisions of CPA Memoranda Provisions and CPA Memorandum Number 7 , Delegation of Authority Under De-Ba'athification Order Number 1: All authority delegated under this Memorandum shall be withdrawn and the Higher National De$\mathrm{Ba}^{\prime}$ athification Council, established pursuant to that authority, shall be abolished at such time as the Iraqi Interim Government issues an order establishing the Independent Iraqi De-Ba'athification Council." Id. $\S 6(7)$.

58. Editorial, Dangers of the Inquisition: How de-Ba'athfication is Helping the Rebels, ECONOMIst, 27 Nov. 2003, at 42. 
Since assuming office at the end of June, Allawi has taken steps to dismantle the de-Ba'athification process. He has appointed a number of $\mathrm{Ba}^{\prime}$ athists to senior positions-most significantly, in the military and intelligence apparatus. Allawi also "cancelled the credentials of all but fifty of the two hundred members of the de-Ba'athification commission, suspended its funding, and dislodged its members from its offices." ${ }^{59}$ But most ominously of all Allawi's office issued instructions to all Ministries to cease cooperating with the HNDC and drafted a law seeking to establish a judicial committee to replace the HNDC. ${ }^{60}$ In the aftermath of the 30 January 2005 elections, Allawi lost the premiership and possibly any other position in the cabinet, and Chalabi looked to be regaining some of the ground he had lost during the previous six months. However, the failure after three months to form a new government and the prolonged negotiations to bring Sunnis into government and to involve them in the process of drafting a new constitution may ultimately impact the de-Ba'athification process and the fate of the HNDC.

\section{TRUTH SEEKING}

Long before the outset of war, international human rights organizations and Iraqis in exile had begun discussing the idea of establishing a truth commission $^{61}$ in Iraq to confront the massive human rights abuses of the Saddam era. ${ }^{62}$ Such a commission could serve several purposes. First, unlike judicial proceedings against a small number of past offenders, an officially sanctioned truth commission could outline the full responsibility of the past regime and its various institutions that carried out or condoned the repression-including not only the military and the police, but also the judiciary itself. Second, a truth commission could provide victims with a forum to have their suffering acknowledged and to help explore the possibility of providing reparations. Third, it could gather and analyze vast amounts of evidence from organizations and individuals both in and outside of Iraq, with the aim of creating an "official" account of crimes against humanity and genocide, such as the "Anfal" campaign and the killing and displacement of Marsh Arabs. Fourth, a truth commission could help promote tolerance and reconciliation within Iraqi society without sacrificing

59. Jon Lee Anderson, Out on the Street, New YORKer, 15 Nov. 2004, at 78.

60. Copy of the draft law on file with authors.

61. For a review of the work of truth commissions over the past twenty years, see PRISCILLA B. Hayner, Unspeakable Truths: Confronting State Terror and Atrocity (2001).

62. See, e.g., the final report of the Working Group on Transitional Justice in Iraq and the Iraqi Jurists Association (Mar. 2003) (on file with the authors). 
accountability or ignoring already existing divisions. Finally, an Iraqi commission could explore the role of external actors in preventing or enabling human rights abuse..$^{63}$

For a truth commission to succeed in Iraq, as in any country, it must be regarded by a broad cross-section of society as legitimate and independent from extraneous political influences; otherwise, it risks being marginalized or having a polarizing effect. In their 2003 survey of Iraqis, ICTJ and Berkeley researchers found that legitimacy and public support for a truthseeking process in Iraq would only emerge through an open, transparent, and inclusive process of public consultation and education. "Among Iraqis in Iraq, there is little knowledge of or exposure to the idea of a truth commission, and not much exposure to other countries' experiences," the researchers said. "Thus, educating the emergent forces of Iraqi civil society, religious and community leaders, representatives of ethnic groups, and a broad cross-section of Iraq's (highly literate) population is an indispensable first step." ${ }^{64}$ Respondents in the ICTJ-Berkeley survey were quick to suggest their own version of how a truth-seeking process should be conducted. Among the suggestions were

establishing local committees of reputable individuals to gather testimony and document the names of the dead and missing ... ; declaring days of remembrance as national holidays; establishing memorials in every town and region; creating museums and documentation centers, photographic and videographic displays, and artistic works of literature, cinema, and theatre; and preserving detention centers and instruments of torture. ${ }^{65}$

By September 2004, neither the CPA nor the IGC had consulted the Iraqi people about the need to establish a truth commission. Even so, CPA officials, largely at the urging of Bremer, had debated the merits of creating such a truth-seeking body since the Special Tribunal was established in December 2003. In early 2004, as a split emerged between the British and the Americans on the question of the Special Tribunal's application of the death penalty, the British made clear that they would not be able to play any direct role in supporting the tribunal process. As a result, it was agreed that, within the CPA's office for human rights and transitional justice, an American would oversee the tribunal's work and a British "advisor," working closely with the newly appointed Iraqi Minister for Human Rights, would oversee the process of establishing a truth commission.

In February 2004, one of the authors (Hanny Megally) met with British

63. See Toward a Truth Commission for Iraq? A Briefing Paper of the International Center for Transitional Justice, Feb. 2004.

64. ICTJ, IRAQI VoICEs, supra note 8 , at $55-56$

65. Id. at 51 . 
and Iraqi officials, including the human rights minister, and representatives of Iraqi civil society to discuss the need for consultation among Iraqis and coordination of the various transitional justice mechanisms being brought into play in Iraq. To their credit the British official and human rights minister accepted that such a process should not be rushed and would be doomed to failure if the CPA failed to consult the Iraqi people. ${ }^{66}$ However, in the ensuing months as US troops sank into the quagmire of Fallujah, Bremer, in need of a success story, applied intense pressure on his underlings to draw up plans for a truth commission and to have commissioners appointed to it by the July deadline for the handover of power to an Interim Iraqi government. At one point Bremer's office set a ten-day deadline for a blue print for a commission to be on his desk, but the task was never completed.

At the time of writing, a new Iraqi government had not been formed; and it remained unclear if Bakhtiar Amin, who had championed the need for a truth commission and had expressed his interest in helping set one up, would retain his position as Minister of Human Rights. It remains to be seen whether, and, if so, in what way, he will seek wide consultation among the Iraqi people before such a decision is made.

In light of the ongoing friction in Iraq regarding the presence of US and coalition forces and the religious, ethnic, and social fault lines that persist, confidence in a nonpartisan and impartial truth-seeking process will have to be built from the ground up. And it must involve all sectors of Iraqi society so that it is not perceived as a dialogue only between "elites" or certain political and ethnic groups.

\section{REPARATIONS}

History has shown that reparations in the form of material and symbolic compensation are essential for victims of massive violations of human rights. They can be as fundamental as one-time financial payments to individual victims or collective processes, such as public memorials, days of remembrance, parks or other public monuments, renaming of streets or schools, preservation of repressive sites as museums, or other ways of creating public memory. They can encompass education reform, the rewriting of history texts, and education in human rights and tolerance. Yet whatever reparations scheme is pursued, writes Naomi Roht-Arriaza, caution must be taken not to use it "to stigmatize and marginalize those groups whose members perpetrated the abuse. Reparations must be offered

66. Correspondence between Hanny Megally and the British Foreign and Commonwealth Office, April 2004 (on file with the author). 
in ways that acknowledge the suffering of victims but do not victimize others who did not actively engage in the violence. ${ }^{167}$

According to the 2003 ICTJ-Berkeley survey, while Iraqis overwhelmingly supported material and symbolic compensation for victims of violations of human rights, they did not necessarily support single-instance ex gratia financial payments. ${ }^{68}$ Many respondents recognized that the losses suffered were incalculable and that no amount of money could replace a family member (or, in some cases, an entire family) who was killed by the regime. Respondents suggested forms of reparations that included providing physical and mental health services and access to education and employment; meeting basic needs for shelter, food, and clothing; returning confiscated property; and establishing memorials inscribed with victims' names. The vast majority of respondents believed that the financial costs of reparations should be borne by the Iraqi state. ${ }^{69}$

The CPA withdrew from Iraq without paying serious attention to the issue of reparations for abuses committed by either the past regime or the US occupiers. Indeed, it was not until 26 May 2004, five weeks before the hand over of power to the Iraqis, that Bremer sought to establish a special task force on reparations for past crimes. "No government or any other institution can erase these past abuses or remove the scars they have left behind," Bremer said. "However, compensation can provide an element of justice to those who suffered under Saddam's brutally oppressive regime." 70

Bremer appointed Malek Dohan al-Hassan, then head of the Iraqi Bar Association, as chair of the task force and instructed him "to work with victims, ministries, and others to define the types of injustice for which compensation should be provided." ${ }^{\prime 71}$ The group was also tasked to decide who would be eligible for compensation, the level of compensation that should be given, and the mechanisms through which it should be delivered. Bremer pledged to provide the task force with $\$ 25$ million for initial compensation payments to victims and to cover the group's operating costs.

In a telling penultimate paragraph to the press release, the CPA noted that

[I]n order for this to be a fully Iraqi process, the CPA has asked that Dr. Malek's report be concluded by August 1, 2004 so that it can be provided to the Interim

67. Naomi Roht-Arriaza, Reparations in the aftermath of repression and political violence, in Mr Neighbor, Mr Enemr, supra note 11, at 123.

68. ICT), IRAQI VoicEs, supra note 8 , at 40 .

69. Id. at 42 .

70. Press Release, Coalition Provisional Authority, Ambassador Bremer Announces Creation of Special Task Force on Compensation for Victims of the Former Regime (26 May 2004), available at www.iraqcoalition.org/pressreleases/20040526_compensation.html.

71. Id. 
Government as soon as possible after the transfer of sovereignty. Iraq's leaders, in the best interests of the Iraqi people, will determine how to act on the recommendations. ${ }^{72}$

In essence the task force was given just over two months to learn about the intricacies of reparations, to study examples from around the world, to conduct its own survey within Iraq, to educate victims and families, and to present its conclusions and recommendations to the interim authorities. Such a truncated process could hardly do justice to such a complex and potentially explosive issue as reparations. Indeed, soon after Bremer's edict, Malek Dohan was appointed Minister of Justice; a month later, the CPA had ceased to exist, and by the end of August the task force had not yet met or begun its work. The task force finally began operating in early 2005 and, by March, had prepared a draft law to be presented to the new Iraqi government. ${ }^{73}$

\section{CONCLUSION}

In his study of post-World War II Japan, historian John Dower noted how profoundly the American occupation affected that defeated nation: "Much that lies at the heart of contemporary Japanese society-the nature of its democracy, the intensity of popular feelings about pacifism and remilitarization, the manner in which the war is remembered (and forgotten)derives from the complexity of the interplay between the victors and the vanquished."74 How an occupying power interacts with the people of a postwar nation can affect that society for decades to come. Unfortunately, the American occupiers of Iraq never comprehended how Iraqis perceived them. Larry Diamond writes:

The coalition lacked the linguistic and area expertise necessary to understand Iraqi politics and society, and the few long-time experts present were excluded from the inner circle of decision-making in the CPA. Thus the coalition never grasped, for example, the fact that although most Iraqis were grateful for having been liberated from a brutal tyranny, their gratitude was mixed with deep suspicion of the United States' real motives (not to mention those of the United Kingdom, a former colonial ruler of Iraq); humiliation that the Iraqis themselves have proved unable to overthrow Saddam; and unrealistic expectations of the postwar administration, which Iraqis expected to quickly deliver them from their problems. Too many Iraqis viewed the invasion not as an international

72. Id.

73. Hanny Megally Interview with Members of the Reparations Task Force, Amman (March 2005).

74. John W. Dower, Embracing Defeat: Japan in the Wake of Worlo War II 28 (1999). 
effort but as an occupation by Western, Christian, essentially Anglo-American powers, and this evoked powerful memories of previous subjugation and of nationalist struggles against Iraq's former overlords. ${ }^{75}$

Lacking an effective political strategy for postwar Iraq, it is easy to understand why the transitional justice mechanisms introduced by the CPA either backfired or were hopelessly flawed. The CPA never understood-or even listened to-the people it was seeking to help. Instead, it adopted an ex cathedra approach by which Bremer alone dictated what mechanisms would be taken. In the case of documentary and physical evidence for future trials, the US-led coalition forces failed to secure the relevant sites at the time of the overthrow of the former government. Nor did they put in place the professional expertise and assistance necessary to ensure proper classification and exhumation procedures, with the result that key physical evidence has been lost or tainted. These failures also have frustrated families of the missing who, after years of silence, wish to know the fate of their loved ones, ${ }^{76}$

Having invaded Iraq without UN Security Council authorization, the United States was unable to convince many countries to take a meaningful role in helping Iraq deal with its violent past, something that could have blunted suspicions of the coalition. Always insisting that it would "go it alone," the CPA implemented accountability measures without properly consulting the United Nations and international human rights organizations, such as Amnesty International, Human Rights Watch, and the International Center for Transitional Justice-all of which possess considerable experience and knowledge of international and national war crimes tribunals. By sidelining these institutions, the CPA deprived Iraqi jurists charged with drafting the statute for the Special Tribunal of a wide range of perspectives on the procedural, evidentiary, and jurisprudential aspects of war crimes trials and the "lessons learned" from vetting and lustration programs in other countries.

It is difficult to measure how the photographs of torture and inhuman and degrading treatment of Iraqi detainees held in Abu Ghraib and other US detention facilities affected the attitudes of ordinary Iraqis toward the CPA and the transitional justice mechanisms it introduced during the occupation simply because no rigorous polling was conducted on that issue at the time. But it stands to reason that the photographs, which were widely circulated in the Iraqi press and repeatedly broadcast by Al-Jazeera and other news outlets in Iraq, must have undermined the legitimacy and authority of the US occupation in the minds of a considerable number of Iraqis. Moreover,

75. Diamond, supra note 2 , at 43 .

76. See Human Rights Watch, Iraq: State of the Evidence, supra note 7, at 2. 
the mass arrests of Iraqi men by US and Coalition forces in the second half of 2003 must have further undermined the legitimacy of the US occupation, especially as 70 to 90 percent of those who were taken into custody, according to military intelligence officers with the coalition forces, "had been arrested by mistake." 77

Clearly, the US-led coalition faced numerous demands when it took military and administrative control of Iraq in April 2003. It needed to quell a growing insurgency and to give immediate attention to numerous infrastructure, public health, and safety needs. By the same token, public statements by the Bush Administration both before and during the occupation placed a high priority on giving Iraqis back their dignity and a stake in their own future. American officials in Washington and Baghdad repeatedly promised to restore the rule of law in Iraq and to hold past human rights offenders accountable. These were lofty pledges-pledges that many Iraqis across the country, as well as many living abroad, embraced.

Missing, however, was the appreciation that confronting a violent past in a multiethnic society is a complex and inclusive process that involves a wide range of stakeholders including victims, bystanders, and perpetrators. It means consulting widely and broadly on the feasibility and applicability of transitional justice measures and, most of all, giving the Iraqis a voice in the process. For in the end, it is the Iraqi people who must unravel the Gordian Knot of past horrors if they are ever to obtain the justice they so clearly desire.

77. See Report of the International. Committee of the Red Cross (ICRC) on the Treatment by the Conlition forces of Prisoners of War and Other Protected Persons by the Geneva Conventions in Iraq During Arrest, Internment, and Interrogration 8 (2004). 